[Vicino Oriente XVI (2012), pp. 1-28]

\title{
COPPER AXES AND DOUBLE-APSES BUILDINGS: INVESTIGATING EB I SOCIAL INTERRELATIONS
}

\author{
Daria Montanari - Sapienza University of Rome
}

Il rinvenimento di depositi di fondazione contenenti asce di rame in relazione ad edifici biabsidati, nel Levante meridionale del Bronzo Antico I (3400-3000 a.C.), risalta sia il valore di queste strutture quali luoghi dedicati ad attività sovrafamiliari e di uso collettivo, sia il valore comunitario di tali armi metalliche.

Keywords: axes; double-apses building; Grey Burnished Ware; Southern Levant; Early Bronze I

\section{PREMISE}

The attempt of this study is to highlight the relationship between copper axes and double-apses buildings ${ }^{1}$ during the Early Bronze I (3400-3000 B.C.) in Southern Levant (fig. 1). The recovery of numerous weapons of this type in connection with such kind of structures of noteworthy dimensions allows the reading, on one hand, of these buildings as community places and, on the other hand, of axes as a community good.

Among numerous copper and bronze axes and adzes known for the whole Early Bronze Age in Southern Levant some forty are dated to the Early Bronze I (EB I). ${ }^{2}$ Some of these were recovered in contexts of different type dated to the EB IB, such as the rich hoard of Kefar Monash, ${ }^{3}$ Building MA of M3 period of Tell el-Hosn/Beth Shan, ${ }^{4}$ and a domestic unit of Tell Abu al-Kharaz of Phase I. ${ }^{5}$ Some others, instead, were collected in other somewhat uncertain contexts of EB I, ${ }^{6}$ as Tell el- ${ }^{\circ}$ Areini, ${ }^{7}$ Nahal Tabor,${ }^{8}$ and Giv'atayim. ${ }^{9}$

Other specimens, sixteen axes and one adze, afterward analyzed, were recovered in connection with double-apses buildings. These buildings, below presented, are widely

1 Double-apses buildings are large structures with two parallels walls joined to form apses at either edges, known in literature as sausage-shaped buildings (Braun 1989b, 15). It must be stressed that the term 'apse' is not used to designate an apsidal building, usually composed by two right angles at one end and a rounded apse at the opposite end (Braun 1997, fn. 6; Golani 1999, 123). A careful examination (Braun 1989b, 18) of architectural remains leaves good exemplars of apsidal type, the one of Tell el-Mutesellim/Megiddo (Engberg - Shipton 1934, fig. 2), and the one of Tell es-Sultan/Jericho (Nigro 2007, fig. 22)

2 They are approximately 110 items. The main part of metal weapons dated to the Early Bronze I comes from grave contexts, but the main part of axes and adzes of the same period belongs to non-funerary deposits.

Hestrin - Tadmor 1963, 266-271, figs. 2, 4, 6.

4 Mazar - Rotem 2009, fig. 13:1-3.

5 Fisher 2008, 74-125, 213-216, fig. 311:1-3.

Miron 1992, 12, 14.

Hestrin - Tadmor 1963, fn. 5; Miron 1992, 14, pl. 5:70.

Miron 1992, 12, n. 38

9 Hestrin - Tadmor 1963, 268, fn. 7, fig. 3. It is probable that this axe, recovered before the beginning of Isserlin's excavations, belonged to a burial of the Chalcolithic - Early Bronze I cemetery. 
attested to in Southern Levant especially in the northern region of the Southern Levant during the EB I. ${ }^{10}$

\section{DOUBLE-APSES BUILDINGS}

In sites included in this note, like as Khirbet Khalalidya/Yiftah'el, Khirbet Sheikh Meser/Meser, Tell el-Hosn/Beth Shan, Qiryat 'Ata, Palmahim Quarry, and Naḥal Alexander, copper axes were recovered in some relation with double-apses buildings, especially in foundation deposits. Some cases, such as Khirbet Khalalidya/Yiftah'el, Khirbet Sheikh Meser/Meser, Tell el-Hosn/Beth Shan and Qiryat 'Ata, more strongly demonstrate the relation existing between double-apses buildings and copper axes; some other, like as Palmahim Quarry, and Nahal Alexander, ${ }^{11}$ because of the uncertainty of the belonging of axes to this kind of buildings, attest simply the presence of axes within sites characterized during the EB I by the presence of double-apses structures.

Sixteen copper axes and one adze were recovered at sites of Khirbet Khalalidya/Yiftah'el, Khirbet Sheikh Meser/Meser, Tell el-Hosn/Beth Shan, and Palmahim Quarry, from EB IA contexts, and at Qiryat 'Ata, dated to the EB IB, and at Nahal Alexander (Kibbutz Ma'abarot), relevant to unspecified sub-period of EB I.

Khirbet Munhata/Horvat Minha, ${ }^{12}$ Tell Umm Hammad esh-Sharqiya, ${ }^{13} \mathrm{Tell} \mathrm{Ai} /{ }^{\circ} \mathrm{Ai},{ }^{14}$ Safat, ${ }^{15}$ and Tell es-Shune North, ${ }^{16}$ only cursively cited due to the paucity of information and data, should be added to sites below analyzed.

Double-apses buildings are often connected with Grey Burnished Ware (GBW), ${ }^{17}$ less often they are associated to GBW and copper axes.

10 Braun 1989b, 15; Enea 1996, 85. Apsidal buildings are well attested to in the initial phase of EB I also in the Southern Syria region, especially in the Leja area (Nicolle - Braemer 2012, 4-8, fig. 3).

11 Another case could be likely encompassed, the site of Rosh Hanniqra. Evidences of an Early Bronze I occupation, corresponding to Stratum II, were exposed on the tell. These are a series of fragments of curvilinear walls partially overlapping each other (Tadmor - Prausnitz 1959, 77-81; Braun 1989a, 10). In the site a copper adze was recovered (Hestrin - Tadmor 1963, fig. 5).

12 In this site rectilinear and curvilinear walls were recognized, possibly some structures belong to a curvilinear building, attributed to the phase 1 (Perrot 1963, 561).

13 In the site (Glueck 1951, 318-328) a curvilinear architecture is attested in Stage I (Helms 1984, 40, fig. 8). In this phase and in the following one GBW bowls are also attested (Helms 1984, figs. 10:1-2; 11:10-12; 1986, fig. 11:2; about GBW at Tell Umm Hammad esh-Sharqiya: Leonard 1992, 84-85, pls. 23:25, 27; 24:1-5).

14 In Lower City an apsidal wall, W.97, belonging to Level I was detected during Marquet-Krause's excavations dated to the beginning of EB I (Marquet-Krause 1949, 21, pl. XCV).

15 In the site of Safat (to the west of Jerusalem), in Trench 7, a segment of curvilinear wall with related floor, built on bedrock and dated to EB I, was identified (Gibson - Ibbs - Kloner 1991, 37, fig. 12).

16 In this site, within Layers 15 and 14 (Perrot 1963, 561), in Level II, dated to EB I, GBW carinated bowls with "S" profile, corresponding to Beth Shan XVI and Khirbet Sheikh Meser/Meser (de Contenson 1961, 547550), were recovered. These bowls fit with Wright Type 1, dating back to EB IA (Gustavson-Gaube 1985, 4388). In following Layer 10, in Level III, two stretches of a circular structure are attested (Lankester Harding 1954, 560; de Contenson 1960, 26, fig. 18:C).

17 Goren - Zuckerman 2000, 174. 


\subsection{Byblos}

It is very difficult to distinguish remains belonging to Dunand's Énéolithic Récent, nearly corresponding to EB IA, between many overlapping structures excavated in the site of Byblos. In this stage the curvilinear architecture seems to be preferred; ${ }^{18}$ circular huts, oval-shaped houses, double-apses, and apsidal buildings are attested; frequently floors are made of beaten earth. ${ }^{19}$ Among all curvilinear and circular dwellings, some can be recognized like as double-apses buildings, ${ }^{20}$ similar to those known in Palestine, even if difficult stratigraphic situations don't allow a sure interpretation and reconstruction of architectonical features.

\subsection{Dakerman}

Oval and double-apses dwellings are attested to at Dakerman, ${ }^{21}$ contemporaneous to those of Byblos. ${ }^{22}$ These structures share with southern buildings the general elliptical feature, with long walls not symmetrically straight, but irregular and somehow bowed; the entrance usually is placed along one long boundary wall. Dakerman buildings are lacking of any installations, paved floors, and inner partition walls. Moreover, the average dimension seems to be smaller in respect of southern structures.

\subsection{Tell Teo}

In the site two main phases belonging to EB I were recognized: Stratum $\mathrm{V},{ }^{23}$ that represents a major phase of construction, and Stratum IV, ${ }^{24}$ only poorly preserved. Three double-apses structures were excavated in Stratum V dated to EB IB: Building 525, Building 542, and Building 557.

Building $525^{25}$ is the largest structure preserved in Stratum V, and it is $5.7 \mathrm{~m}$ wide and $12.5 \mathrm{~m}$ long. The northern end of the structure was damaged during the removal of an ancient terebinth (Pistacia palaestina). The preserved portion consist of one curved end wall (W.524) and two parallel long walls (W.527, W.507); its reconstruction as a doubleapses building is based on analogy with other structures in the same stratum. The interior space of Building 525 was subdivided by a curved partition wall (W.506), which may have had a role in supporting the roof. The southern room (L.510) was partially paved with large

8 Nigro 2007, 22.

19 Dunand 1950, 590.

20 Buildings 18 and 35 (Dunand 1973, pls. J,a; J,b), and maybe the structure visible in square 10/7 - Stage 15 (Dunand 1973, pl. J,b). The first, that is the only complete, is roughly $5 \mathrm{~m}$ long and seems to have within some installations, paved floor, and a sort of posthole.

21 Saidah 1979, 33-38, fig. 2.

22 Nigro 2007, 22.

23 Eisenberg - Gopher - Greenberg 2001, 39-43. Stratum IV is characterized, like Stratum V, by a number of curved wall fragments that composed some curvilinear structures. Stratum IV consisted of poorly preserved architectural remains.

24 Eisenberg - Gopher - Greenberg 2001, 43-46.

25 Eisenberg - Gopher - Greenberg 2001, 39, plan 3.9. 
slabs, in correspondence of the apse. A similar pavement was exposed in the northern room (L.525). ${ }^{26}$

Building $542^{27}$ is seven meters to south-west of Building 525, and it was preserved a somewhat greater extent. Although the southwestern part of the structure was missing, probably destroyed by Stratum IV construction activities, it could be reconstructed as a curvilinear structure, measuring $6 \times 11 \mathrm{~m}$. The entrance was located in the middle of northern wall (W.546). A flat step was sunk in the floor before the threshold in the courtyard. On the east, in correspondence of the eastern apse, a stone-paved area (L.517) was found; a complete GBW bowl ${ }^{28}$ was found on this floor (L.517 near W.520).

Building $557^{29}$ was excavated only in the northern part revealing a curved edge and two parallel long walls, about $4 \mathrm{~m}$ apart, oriented north-south. A segment of plastered floor with crushed limestone and small pebbles was recognized. Two infant burials were found, one, Burial B2 ${ }^{30}$ beneath the floor, and the other, Burial B $3,{ }^{31}$ under the eastern boundary wall.

\subsection{Horvat Avot}

In the site of Horvat Avot a segment of apsidal wall has been recognized in association with some GBW bowl fragments, ${ }^{32}$ comparable with sherds recovered at Tell Teo, ${ }^{33}$ dated to EB IA.

\subsection{Tell Kabri}

In Area B, a curvilinear building, Building 1118, belonging to Stratum 10 and dated to EB IA, comprising a curved wall and a partition wall, was exposed in Squares J/11-12. This partition wall (W.1108) divided the structure in correspondence of the possible apse. ${ }^{34} \mathrm{~A}$ large quantity of sherds of GBW was found on floors of rooms and courtyard of Building $1118 . .^{35}$

In Stratum 9, dated to EB IB, in Square J/11-12 and K/11-12 a double-apses building was uncovered, Building $1057(8.8 \times 4.3 \mathrm{~m})$, founded over a layer of fill covering remains of Building $1118 .{ }^{36}$ The structure of Stratum 9 has a $1 \mathrm{~m}$ wide entrance placed within the southern long wall, and with two steps descending into it. Three limestone column bases were aligned to the north of the longitudinal axis; they were arranged in a row, separated by

26 The sole ceramic finding on the floor of this structure was represented by a red-slipped and burnished carinated bowl (Eisenberg - Gopher - Greenberg 2001, fig. 7.2:9). An infant burial, Burial B1 (Eisenberg Gopher - Greenberg 2001, fig. 3.34), was found beneath the pavement placed in a jar whose base had been removed.

27 Eisenberg - Gopher - Greenberg 2001, 39, plan 3.9.

28 Eisenberg - Gopher - Greenberg 2001, 39, figs. 3.36; 7.2:1.

29 Eisenberg - Gopher - Greenberg 2001, 39, plan 3.9.

30 Eisenberg - Gopher - Greenberg 2001, fig. 3.37.

31 Eisenberg - Gopher - Greenberg 2001, fig. 3.38.

32 Braun 1981, 107-108.

33 Braun 1989a, 10.

34 Scheftelowitz 2002a, 23.

35 Scheftelowitz 2002b, 96, fig. 5.3:1-6.

36 Kempinski - Niemeier 1991, fig 1. 
almost identical distance. In the fill beneath the north-western curved boundary wall, W.1018, a jar burial was found, T.1107. ${ }^{37}$ Three floors were recognized; the lowest was the best preserved; ${ }^{38}$ a seal impression, with a human figure raising its arms standing next to a building, was found on the second floor..$^{39}$

In the same stratum a second curvilinear structure, Building 977, was exposed, built up over an earth filling containing EB IA pottery sherds, as nearby Building 1057, but in contrast with it, Building 977 is smaller. ${ }^{40}$ A chalk floor was recognized and, beneath it, a jar burial, T.1046, was found. ${ }^{41}$

\subsection{Beth Ha'Emeq}

Two incomplete buildings with apsidal edges were uncovered in the site of Beth Ha'Emeq together with pottery dated to EB I, corresponding to Strata VI-III. ${ }^{22}$ Among these buildings, one preserved a pillar base in correspondence of the apse; the other has the entrance opened into one long boundary wall. ${ }^{43} \mathrm{GBW}$ bowls were recovered in layers below buildings with apses. ${ }^{44}$

\subsection{Qiryat 'Ata}

Building 2 of Stratum III in the Area A of Qiryat 'Ata is dated to the initial phase of the EB IB. ${ }^{45}$ It is east-west oriented and has a double-apses plan (fig. 2), ${ }^{46}$ albeit the eastern wall is the only preserved circumference; the western circumference wall, in facts, was hewn out of the bedrock. ${ }^{47}$ The plan is tripartite by two inner partition walls in two roughly symmetrical lateral rooms, such as in Building IIA/1 of Khirbet Khalalidya/Yiftah'el, and a central hall, furnished with a central row of four stone pillar bases. ${ }^{48} \mathrm{~A}$ cache of copper

37 The brownish-red jar contained remains of skulls of two children and two faïence beads (Scheftelowitz 2002a, 29).

38 Scheftelowitz 2002a, 25

39 Kempinski 2002, 339-340.

40 Scheftelowitz 2002a, 23, 25

41 T.1046 is a multiple infant burial in a large storage jar, containing thirteen faïence beads and one carnelian bead, farther skeletal remains (Scheftelowitz 2002a, 29).

42 Frankel - Kempinski 1973, 242, pl. 66:A.

43 Enea 1996, fig. 3.

44 Frankel - Kempinski 1973, 242, pl. 66:A.

45 Several GBW sherds were recovered in the whole site of Qiryat 'Ata, and within Building 2 on its floors (Golani 2003, 83-88, fig. 4.2:1, 6, 9-10, 17, table 4.13)

46 Outer dimensions of the building are $7.15 \times 18.15 \mathrm{~m}$. The size, the architectural feature of this structure, and the material recovered inside it suggest a public function instead of/or in addition to a domestic one (Golani $2003,19)$. Within the main hall of the building, masses of large storage pithoi were found crushed on the floor, indicating the presence of nearly 130 storage jars (Faust - Golani 2008, 218). Building 2 is almost twice in respect of near houses. It has been suggest (Faust - Golani 2008, 228-229) that this building could house the village chief, according to artifacts within the structure and to inner subdivision, differentiating a ceremonial/public part of the building from a private one, and indicating a sort of communitarian storage/redistribution.

47 Golani 2003, 19.

48 On the floor of the central hall were collected some GBW bowls (Golani 2003, figs. 4.2:17; 4.15:8, 12), late variants of the Early Bronze IA GBW bowls attested in the Stratum II of Khirbet Khalalidya/Yiftah'el, 
tools was found close to bedrock, near the lowest course of stones directly outside the upslope northern wall of Building 2. The cache consisted of a thin, elongated, triangularshaped blade and a complete axe (fig. 12); a chisel was placed on either side of the axe. This cache was near the bottom level of this lower course with apparently all copper tools purposefully arranged and set into place, ${ }^{49}$ being apparently a foundation deposit. ${ }^{50}$

\subsection{Khirbet Khalalidya/Yiftah'el}

Two fan-shaped copper axes were recovered at the site of Khirbet Khalalidya/Yiftah'el, inside two different and contemporaneous double-apses buildings.

Building IIA/1 of Stratum II (fig. 3) is one of the best preserved structures in the site; its double-apses plan was entirely exposed. ${ }^{51}$ The building is inwardly tripartite in two lateral irregular rooms divided from the central hall by two curvilinear inner walls, ${ }^{52}$ and apses were paved with stone slabs. The first axe recovered (fig. 7:1), ${ }^{53}$ together with some pottery sherds, including GBW, ${ }^{54}$ was on the floor related to the latest occupation of the building, corresponding to the EB IA..$^{55}$

Building IIB/1 of Stratum II (fig. 4) is the largest building underneath in the site. ${ }^{56}$ The plan is conformed according the double-apses type, subdivided into irregular chambers by the addition of inner curvilinear walls; numerous pottery fragments, including GBW bowls, ${ }^{57}$ and the second axe (fig. 7:2) were collected inside chambers; $;{ }^{58}$ the axe was located immediately to the west of the inner curvilinear partition wall in correspondence of lower elevation of foundations. ${ }^{59}$

A third double-apses building of noteworthy dimensions uncovered in the site of Khirbet Khalalidya/Yiftah'el is Building IIA/2.60 This is placed to the south of Building IIA/1. This structure has an inner horseshoe partition wall that divided a paved area, in correspondence of the southern apse, and the main hall of the structure. The majority of

sharing with those the same kind of clay (Golani 2003, 149), and some fragmentary basalt vessels (Rowan 2003, fig. 6.4:5, 9)

49 Golani 2003, 23.

50 Faust - Golani 2008, 218. Another two axes, dated to EB IB, were collected from the surface of the site (Fantalkin 2000, 50, figs. 17:6, 18:5-6).

51 The building altogether is roughly $16.5 \mathrm{~m}$ long and $6 \mathrm{~m}$ wide (Braun 1997, plan 3).

52 Braun 1997, 31, fig. 6:11.

53 Braun 1997, 31, fig. 11.3:2

54 One fragmentary GBW bowl was collected inside the Building IIA/1 (Braun 1997, pl. 9.2:8).

55 Braun 1997, 30-31.

56 It is probably more than $17 \mathrm{~m}$ long and $7.5 \mathrm{~m}$ wide (Braun 1997, plan 4).

57 Braun 1997, fig. 9.2:7.

58 Braun 1997, 38, fig. 11.3:1.

59 Braun 1997, 37-39.

60 Braun 1997, 31-32, fig. 6:15. 
potsherds were around this wall and among these were several fragments of GBW bowls, ${ }^{61}$ including a portion of fenestrated bowl. ${ }^{62}$

\section{9. 'En Shadud}

An irregular double-apses building, within Area A in the site of 'En Shadud ${ }^{63}$ dated to an advanced phase of EB I, was uncovered. This building has the entrance along its southern long boundary wall, a central row of three pillar bases, and a bench to the west nearby the entrance. ${ }^{64}$ Numerous pottery fragments of GBW were recovered, ${ }^{65}$ most of these belong to Goren and Zuckerman's ${ }^{66}$ Family III ${ }^{67}$ and only one sherd to Family I. ${ }^{68}$

\subsection{Tell el-Hosn/Beth Shan}

A double-apses structure (fig. 5), ${ }^{69}$ built up with flat mudbricks, was discovered in the deep sounding of the tell in Level XVI, ${ }^{70}$ corresponding to EB IA. ${ }^{71}$ A copper axe and an adze (fig. 10) were recovered at the southern edge of the building, close to the threshold. ${ }^{72}$ Also in this case the copper items might belong to a foundation deposit.

\subsection{Tell Assawir}

A densely built up area in Stratum GVI - GV, corresponding to general stratum III of the site, and to the early phase of EB I, in Area G, on the eastern slope of the hill, was recognized ${ }^{73}$ it is characterized by oval structures and curvilinear wall. ${ }^{74}$

In Stratum GIV, a straight wall $10 \mathrm{~m}$ long is exposed; this seems to be connected in its northern part to another wall non perpendicular by two large stones. They might belong to a public structure. ${ }^{75}$

61 Braun 1997, pls. 9:2; 9:4:1, 3 .

62 Several wide-mouth pithoi were also recovered, presumably related to a storage of dry goods, but the presence of seven fragmentary bowls of GBW suggests that the storage was not the only activity of this room (Braun 1997, 32).

63 Braun 1979, 234-235, pl. 27:F.

64 Braun 1985, 17, 68, figs. 5-6, 31.

65 Braun 1985, 38, 41, 43, 65-66, figs. 18-19.

66 Goren - Zuckerman 2000, 172.

67 Braun 1985, fig. 19:1-10.

68 Braun 1985, fig. 18:13. Only some sherds were recovered inside the double-apses building (Braun 1985, figs. 18:13, 19:4, 7, 9-10).

69 Initially the structure was claimed to be of apsidal form (FitzGerald 1934, 126-127; 1935, 9). Because of the irregular exterior aspect it does not meet criteria of apsidal type; it may be considered to be more close to double-apses structures found at other sites, such as Dakerman, Khirbet Khalalidya/Yiftah'el and Khirbet Sheikh Meser/Meser, sharing with those also some architectural features, such as stone pavements (Braun 1989a, 5; 2004, 16, fig. 2:19). Altogether the building is about $9 \mathrm{~m}$ long and $5 \mathrm{~m}$ wide.

70 FitzGerald 1934, pl. III:1; FitzGerald 1935, 9.

71 Grey Burnished bowls are associated to this phase (FitzGerald 1935, pl. III:1-2, 4.) similar to some other recovered in contemporaneous Khirbet Khalalidya/Yiftah'el (Shalev - Braun 1997, 94).

72 FitzGerald 1934, 127

73 Yannai 2006, 55-57.

74 Resembling the construction at Khirbet Khalalidya/Yiftah'el and Dakerman of EB IA. 
GBW bowl sherds were collected in layer dated to EB IA all over the site and especially in Area G. ${ }^{76}$

\subsection{Tell Jenin}

At Tell Jenin some structures related to buildings with apses, dated to EB IB, were uncovered. ${ }^{77}$ In Site 3 two different maybe double-apses buildings with fenced courtyard were exposed, characterized by two superimposed phases of use ${ }^{78}$ among these buildings, the former is excavated in its northern half; the latter is known only in a segment of a boundary wall.

\subsection{Khirbet Sheikh Meser/Meser}

Some curvilinear structures belonging to Stratum II (fig. 6), dated to the beginning of EB I, were recognized at the site of Khirbet Sheikh Meser/Meser. ${ }^{79}$ More exactly, a long curvilinear wall, in the Area $\mathrm{B}$, originally read such as an apsidal one, ${ }^{80}$ is probably the boundary wall of a double-apses building, similar to those known from Khirbet Khalalidya/Yiftah'el. ${ }^{81}$ A cache of five copper axes (fig. 8) ${ }^{82}$ was found directly beneath the curvilinear wall of Stratum II (fig. 9), dated to the EB IA. ${ }^{83}$ The cache, adjacent to and partially covered by the base of the curvilinear wall, seems to have been placed there intentionally, being a sort of foundation deposit. ${ }^{84} \mathrm{GBW}$ bowls recovered in the site, and attributed to strata I and II, belong to Goren and Zuckerman's Family I. ${ }^{85}$

\subsection{Nahal Alexander (Kibbutz Ma'abarot)}

Surveys and excavations conducted along banks of the Alexander River showed the remains of two subsequent phases of occupation of the site of Nahal Alexander, relative to EB I, the first one, and to Middle Bronze I, the second one. ${ }^{86}$ Curvilinear wall stretches were attributed to Early Bronze ${ }^{8}{ }^{87}$ according also to the pottery recovered, which included Red Burnished Ware, Line-Painted Ware, ${ }^{88}$ and Grey Burnished Ware.$^{89}$ Five axes (fig. 13)

75 Yannai 2006, 57.

76 Yannai - Lazar-Shorer - Grosinger 2006, 84-86, table 4:2, pls. 4:49, 4:61, 4:65, 4:67.

77 Salem 2006, 83.

78 Salem 2006, 83-84, figs. 3:12-3:15.

79 Dothan 1957, 218, fig. 1. The case of the cache of Khirbet Sheikh Meser/Meser is debated, being alternatively dated to the end of Chalcolithic (Miron 1992, 11; Shalev - Braun 1997, 94, note 4) or to the beginning of EB I, but the date for the cache to EB IA seems to be more acceptable (Golani 2003, 215). It is probable that the building recognized at Khirbet Sheikh Meser/Meser represents the most ancient building of double-apses type attested to in Southern Levant (Thompson 1969, 69).

80 Dothan 1957, 218. The curvilinear wall is $12 \mathrm{~m}$ long.

81 Braun 1989a, 6

82 Dothan 1957, 220.

83 Golani 2003, 215.

84 Golani 2003, 215

85 Dothan 1957, fig. 2:2-3; 1959, figs. 6:1-5, 8:1-3; Goren - Zuckerman 2000, 172.

86 Dar 1989-1990, 50

87 Braun 1989a, 16.

88 Sala 2005, 171-177. 
were accidentally discovered during fish-pound works and, even if they were fortuitous finds, it is likely that they belonged to the EB I occupation,,$^{90}$ considering also the pottery repertoire and contexts previously analyzed.

\subsection{Azor/Yazur}

In Area $\mathrm{B}^{91}$ remains of a double-apses building on stone foundation were recovered ${ }^{92}$

\subsection{Palmahim Quarry}

Stratum 3 is the earliest coherent stratum represented by architectural remains on the site of Palmahim Quarry and it is dated to EB IA. ${ }^{93}$ This phase is noteworthy for the presence of two complete double-apses buildings, ${ }^{94}$ recovered in Area B, associated with ceramic fragments, including GBW bowls, closely paralleled in the northern site of Khirbet Khalalidya/Yiftah'el, ${ }^{95}$ many of which belonging to Goren and Zuckerman's Family I. ${ }^{96}$ Two fan-shaped copper axes (fig. 11) with other findings belonging to EB I, were collected in the site during the excavation conducted in 1988.

Unfortunately the original context of recovery of axes is unknown; but typological features of these copper weapons fit with characteristics of coeval fan-shaped axes retrieved inside double-apses buildings.

\subsection{Moza}

The first settlement of the site is dated to EB I ${ }^{97}$ corresponding to Stratum V. The only structure associated to this stratum is Building $20^{98}$ that was covered by a layer of mudbrick debris and black burnt soil, indicating that the structure was most likely destroyed by fire. Only the southern edge of Building 20 was uncovered, comprising the curvilinear wall of an apse (W.27) edge of a probable double-apses building. A segment of a slightly curved inner partition wall, formed of a single row of stones and $0.4 \mathrm{~m}$ wide, was also uncovered. The floor was partly paved with flat stones in correspondence of the apse. ${ }^{99}$

The pottery repertoire related to Building 20 dates back to EB I. ${ }^{100}$

89 Dar 1989-1990, 50.

90 Dar 1989-1990, 46.

91 Dothan 1960, 395.

92 Dothan 1958, 273.

93 The earliest evidence for utilization of the site is dated to the Pottery Neolithic period; a later Chalcolithic occupation of the site is also recognized, although it is restricted to small deposits above the bedrock (Braun 2000, 114)

94 One of these buildings measures roughly 6 × $12 \mathrm{~m}$ (Braun 1991, fig. 20).

95 Braun 2000, 114. Material dated to the Early Bronze I is found also in others areas of the site suggesting the possibility that the settlement may have extended over a considerable area (Reich 1988-1989, 144; Braun 1991, 22-23).

96 Goren - Zuckerman 2000, 172.

97 Eisenberg 1993, 41.

98 Eisenberg 1993, plan 1.

99 Eisenberg 1993, 41-42.

100 Curvilinear architecture indicates a connection with the northern culture, ceramic aspects appear to bind Moza with the culture of southern region of Southern Levant (Eisenberg 1993, 43, 47, figs. 3-4). 


\subsection{Ashqelon/Afridar}

Two strata dated to EB IA were discerned in Area M at Ashqelon/Afridar. ${ }^{101}$ In the northern portion of the excavated area, an oval mudbrick structure belonging to Stratum I, possibly a double-apses building, was exposed. The building is a broadroom ${ }^{102}$ with a one meter wide entrance in its eastern long boundary wall. Outside the entrance, to the south, remains of a copper-melting installation were identified. ${ }^{103}$ Within the structure a beaten earth floor was recognized; the northern apse was divided into several small places, probably intended for storage. ${ }^{104}$ Along the presumed central axis of the building two postholes were distinguished.

\section{COMMON ARCHITECTURAL FEATURES}

It might highlight that double-apses buildings have a finished plan: it is not easy feasible enlarging them by juxtaposing new rooms, being in this way probably unsuitable for domestic purposes.

Some common features among double-apses buildings can be traced:

- the floor elevation is lower in respect of outer flooring (like as at Tell Teo, Khirbet Khalalidya/Yiftah'el, 'En Shadud, Tell Kabri)

- the entrance is often opened in long boundary walls (like as at Tell Teo, Khirbet Khalalidya/Yiftah'el, Beth Ha'Emeq, 'En Shadud, Tell Kabri, Ashqelon/Afridar)

- often floors, especially within apses, are paved with flat stone (like as at Tell Teo, Khirbet Khalalidya/Yiftah'el, Moza)

- usually there is one or two inner partition walls, often in correspondence of apses and linked with some installations (like as at Tell Teo, Khirbet Khalalidya/Yiftah'el, Tell Kabri, Moza). These walls could be curvilinear and, in larger buildings, have also a static function. When inner partition walls are missing there is a central row of columns, also with static function (like as at Tell Kabri, Beth Ha'Emeq, Ashqelon/Afridar)

- Sometimes (Tell Teo, Tell Kabri) infant jar burials are under floors of double-apses buildings.

Double-apses buildings, according to dimensions, architectural features, and material repertoire, are possibly common buildings for social activities. ${ }^{105}$ Double-apses building maybe created a distinction between urban and rural settlements. ${ }^{106}$

\section{TYPOLOGICAL ANALYSIS OF COPPER AXES}

Among southern Levantine repertoire, axes dated to EB I appear to be derived from Chalcolithic prototypes; ${ }^{107}$ while morphologically they share a basic trapezoidal shape,

101 Golani 2008, 19.

102 The structure measures 4 x 8 m (Golani 2008, 25).

103 Golani 2008, 22. Similar installation were uncovered in the site also in Area E (Golani 2004, 17-18).

104 Golani 2008, 23.

105 It has been proposed that apses were employed as a storage place (Salem 2006, 85), as it is in the case of Ashqelon/Afridar (Golani 2008, 23).

106 The curvilinear plan was abandoned because incompatible with urban plan (Kempinski 1978, 11).

107 Shalev - Braun 1997, 94. 
those of earlier period tent to be longer and thinner, later specimens, dated to Early Bronze Age, seem to be thicker and massive with more accentuate fan-shaped blade, such as in cases of axes from Khirbet Khalalidya/Yiftah'el, Tell el-Hosn/Beth Shan, Palmahim Quarry, dated to EB IA, Qiryat 'Ata, dating back to EB IB, and Nahal Alexander.

Axes encompassed by this analysis are characterized by a marked fan-shaped blade, thick rectangular cross-section, and biconvex longitudinal section. ${ }^{108}$ The length varies from $11 \mathrm{~cm}$ to $21.5 \mathrm{~cm}$; the maximum width registered is $10.8 \mathrm{~cm} .^{109}$

All axes are likely made of almost pure copper, ${ }^{110}$ as demonstrated by some metallographic analysis. ${ }^{111}$

Axes recovered at Khirbet Sheikh Meser/Meser (figs. 8-9) ${ }^{112}$ share some features with Chalcolithic prototypes, being also one of the ancient samples attested to during EB IA. They show an elongated shape and a bulged cross-section.

Specimens from Khirbet Khalalidya/Yiftah'el (fig. 7), ${ }^{113}$ now preserved in the Israel Museum at Jerusalem, have a fan-shaped blade with slightly bulged cross-section and biconvex longitudinal section.

Axes retrieved at Palmahim Quarry (fig. 11) are similar to those from Khirbet Khalalidya/Yiftah'el; they have a fan-shaped blade with bulged cross-section and biconvex longitudinal section. ${ }^{114}$

Weapons discovered in Level XVI at Tell el-Hosn/Beth Shan (fig. 10) show a prominent fan-shaped blade; among these two specimens only one (fig. 10:2) ) $^{115}$ shares with previous the biconvex longitudinal section; the latter (fig. 10:1) has a thin thickness unlikely other specimens. ${ }^{116}$

108 The maximum thickness registered ranges from 1 to $2 \mathrm{~cm}$. There is only one exception, the adze from Tell elHosn/Beth Shan (FitzGerald 1935, pl. III:21), that is thinner than $1 \mathrm{~cm}$, however it preserves distinctive morphological features shared whit Early Bronze I axes before analyzed.

109 Specimens showing more variability in dimensions are those from Nahal Alexander, they represent also the biggest axes among those currently treated; the smallest axe was recovered at the site of Palmahim Quarry (Reich 1988-1989, 144, fig. 122 on the right).

110 FitzGerald 1935, 9; Dothan 1957, 220; Reich 1988-1989, 144; Shalev - Braun 1997, 93-95; Golani $2003,22$. The Chalcolithic hoard from Nahal Mishmar (Bar-Adon 1980; Philip 1988, 197-198) consists almost entirely of copper objects, suggesting that copper was the basic medium for the production of valuable items at this time.

111 Like as two axes from Khirbet Khalalidya/Yiftah'el and as the one analyzed from Nahal Alexander, in which the average of copper is respectively $99.85 \%, 99.68 \%$ (Shalev - Braun 1997, tab. 11.2), and 99\% (Dar 19891990, tab.2).

112 Among five copper axes recovered at Khirbet Sheikh Meser/Meser the biggest is $19.6 \mathrm{~cm}$ long, $4 \mathrm{~cm}$ wide, and $1.2 \mathrm{~cm}$ thick; the smallest is $13.7 \mathrm{~cm}$ long, $2.7 \mathrm{~cm}$ wide, and $1.5 \mathrm{~cm}$ thick (Miron 1992, 11).

113 The first (fig. 6:1; Shalev - Braun 1997, fig. 11.3:2) is $12 \mathrm{~cm}$ long, $5.2 \mathrm{~cm}$ wide, $1.4 \mathrm{~cm}$ thick and weights 403 g. The second (fig. 6:2; Shalev - Braun 1997, fig. 11.3:1) is $12.6 \mathrm{~cm}$ long, $7 \mathrm{~cm}$ wide, $1.4 \mathrm{~cm}$ thick, and weights $492 \mathrm{~g}$.

114 The first (fig. 10:1; Reich 1988-1989, 144, fig. 122) is $10.9 \mathrm{~cm}$ long, $4.1 \mathrm{~cm}$ wide, $1 \mathrm{~cm}$ thick. The second (fig. 10:2; Reich 1988-1989, 144, fig. 122) is $13.7 \mathrm{~cm}$ long, $6.2 \mathrm{~cm}$ wide, $1.4 \mathrm{~cm}$ thick.

115 The axe is $13.5 \mathrm{~cm}$ long, $6.4 \mathrm{~cm}$ wide, and 1.3 thick (FitzGerald 1935, tav. III:23).

116 The axe is $16 \mathrm{~cm}$ long, $6.6 \mathrm{~cm}$ wide, and $0.6 \mathrm{~cm}$ thick (FitzGerald 1935, tav. III:21) 
The axe recovered at Qiryat 'Ata (fig. 12) is similar to those from Khalalidya/Yiftah'el and Palmahim Quarry, with a fan-shaped blade with slightly bulged cross-section and biconvex longitudinal section.

Axes retrieved at Nahal Alexander (fig. 13) conversely to other specimens cited, are larger and show an expanded and prominent fan-shaped blade. ${ }^{117}$

\section{GREY BURNISHED WARE ${ }^{118}$}

At Tell Teo GBW bowls were retrieved in Strata V and IV, both phases attributed to EB I, and they belong to Family I. GBW bowls from Horvat Avot ${ }^{19}$ are attributed to the same family, and they are directly comparable to those from Tell Teo. ${ }^{120}$

At Kabri a large quantity of sherds of GBW was found on floors of double-apses Building $1118,{ }^{121}$ belonging to Family I, and dating to EB IA.

GBW bowls were attributed to strata VI-III at the site of Beth Ha'Emeq and their form fit with Family I, ${ }^{122}$ although typologically they seem to be unique. ${ }^{123}$ Several pottery fragments of GBW were recovered at 'En Shadud, ${ }^{124}$ most of these belong to Family III, ${ }^{125}$ and only one sherd to Family I. ${ }^{126}$ At Tell Umm Hammad esh-Sharqiya, in some cases GBW bowls attested to fit with Wright's Type $1,{ }^{127}$ Type $2,{ }^{128}$ and Type $3,{ }^{129}$ in other cases it seems that some bowls are a sort of combination between Type 2 and $3 .{ }^{130}$ At Khirbet Munhata/Horvat Minha some GBW sherds, comparable to the repertoire from Tell el-

117 Among five axes, one axe (fig. 13:1; Dar 1989-1990, 46, fig. 2) is $23 \mathrm{~cm}$ long, $10.8 \mathrm{~cm}$ wide, and $1.6 \mathrm{~cm}$ thick; another (fig. 13:2; Dar 1989-1990, 46, fig. 3 ) is $21.3 \mathrm{~cm}$ long, $10 \mathrm{~cm}$ wide, and $1.5 \mathrm{~cm}$ thick.

118 Grey Burnished Ware, occurring nearly in all sites previously cited, was identified at first by G.E. Wright (1937, 42-44) like as Esdraelon Ware. Subsequently Wright (1958, 37-45) distinguished four principal types (Type 1-4), establishing that Type 1 basically is representative of EB IA, and Types 3 and 4, the latest types to spread, are hallmarks of EB IB, and that GBW is indicative of the EB I stages in Northern Palestine, and contemporary to the Red Burnished and Line Painted Wares of southern EB I sites. A new typological and technological classification was made by Goren and Zuckerman (2000, 165-182), recognizing four major families (Family I-IV), mainly corresponding to Wright's types, highlighting that GBW was manufactured locally with a regionalized distribution. Therefore Family I, III and IV were produced mainly, but not only, in the area of the Jezreel Valley, and its subsidiary valleys; additional smaller places of production for Families III and IV can be located in the western Galilee and the central Jordan Valley, suggesting that manufacture of these vessels was less centralized than the manufacture of Family I (Goren - Zuckerman 2000, 175, 179-182).

119 Braun 1981, 107-108.

120 Braun 1989a, 10.

121 Scheftelowitz 2002b, 96, fig. 5.3:1-6.

122 Goren - Zuckerman 2000, 171.

123 Goren - Zuckerman 2000, 171. The slip of bowls of earlier strata, V-IV, is very thick and highly burnished; the bowls of Stratum III, found within and around curvilinear buildings, are characterized by a 'degenerated' grey slip (Goren - Zuckerman 2000, 171).

124 Braun 1985, 38, 41, 43, 65-66, figs. 18-19.

125 Braun 1985, fig. 19:1-10; Goren - Zuckerman 2000, 172.

126 Braun 1985, fig. 18:13. Only some sherds were recovered inside the double-apses building (Braun 1985, figs. 18:13, 19:4, 7, 9-10).

127 Leonard 1992, pl. 24:1, 4-5.

128 Leonard 1992, pl. 23:26.

129 Leonard 1992, pl. 23:9.

130 Leonard 1992, pls. 23:25, 27; 24:2. 
Hosn/Beth Shan, were recovered in layers belonging to phase 1. ${ }^{131}$ At Tell Assawir several sherds of GBW bowl were recovered in Area G, Level III, within the curvilinear building; they belong to Family I, ${ }^{132}$ and to Family III. ${ }^{133}$

GBW bowls (fig. 14) are attested to in sites like as Qiryat 'Ata, Khirbet Khalalidya/Yiftah'el, Tell el-Hosn/Beth Shan, Khirbet Sheikh Meser/Meser, Nahal Alexander, ${ }^{134}$ and Palmahim Quarry, where copper axes were uncovered in connection with double-apses buildings, ${ }^{135}$ especially in the case of Khirbet Khalalidya/Yiftah'el, where a GBW bowl and a copper axe laid on the same floor of Building IIA/1.

GBW bowls recovered at Khirbet Khalalidya/Yiftah'el, ${ }^{136}$ Tell el-Hosn/Beth Shan, ${ }^{137}$ Khirbet Sheikh Meser/Meser, ${ }^{138}$ and Palmahim Quarry ${ }^{139}$ belong to Family I (fig. 14:1-8) and dated to EB IA. These bowls are characterized usually by a lustrous slip, decoration with flat individual knobs, or a crown of linked shallow knobs, pronounced carination in the middle of the body. The slip color ranges from pale yellow through grey to black. The clay is usually buff. This family has been broken in two subfamilies: simple bowls, and bowls in fenestrated pedestal. ${ }^{140}$

GBW bowls uncovered at Qiryat 'Ata belong to Family III (fig. 14:9-12), except that in the case of one rim fragment that probably belong to Family I (fig. 14:8), ${ }^{141}$ and dated to EB $\mathrm{IB} ;{ }^{142}$ a GBW bowl was retrieved on the floor related to the cache in Building 2. Family III includes deep bowls with a thickened rim, sharp carination and no outer decoration. The slip is usually thin and tends to peel off. The clay is generally buff, rich in dark basaltic inclusions. ${ }^{143}$

\section{COPPER AXES, DOUBLE-APSES BUILDINGS, AND GREY BURNISHED WARE: A CASE OF STUDY}

The presence of $\mathrm{GBW}^{144}$ among the pottery repertoire of double-apses buildings is noteworthy. Considering that GBW bowls functioned more as a decorative or evensocially-related artefacts, than as an every-day serving bowls, ${ }^{145}$ the association of this kind of pottery with curvilinear buildings, in which copper axes were recovered, allows the

131 Perrot 1963, 561.

132 Yannai 1999, 210; Yannai - Lazar-Shorer - Grosinger 2006, pl. 4:67:7-10.

133 Yannai - Lazar-Shorer - Grosinger 2006, pl. 4:67:1-6.

134 Unfortunately the presence of GBW in this site is only cited (Dar 1989-1990, 50).

135 Braun 1989b, 19.

136 Braun 1997, pls. 9:2-9:4, specially a bowl (Braun 1997, fig. 9:2:8) from Building IIA/1 and a bowl from Building IIB/1 (Braun 1997, fig. 9:2:7); Goren - Zuckerman 2000, 173.

137 FitzGerald 1935, pl. III:1-2, 4.

138 Dothan 1957, fig. 2:2-3; 1959, figs. 6:1-5, 8:1-3; Goren - Zuckerman 2000, 172-173.

139 Braun 2000, 114; Goren - Zuckerman 2000, 172.

140 Goren - Zuckerman 2000, 167.

141 Golani 2003, fig. 4.2:17.

142 Golani 2003, 83-88, fig. 4.2:1, 6, 9-10, 17, table 4.13.

143 Goren - Zuckerman 2000, 167.

144 Nigro 2006, 10-11.

145 Goren - Zuckerman 2000, 176. 
interpretation of those structures as communitarian buildings, ${ }^{146}$ more than simply and merely domestic units, and encourages, furthermore, the interpretation of such weapons as a community goods with a some kind social meaning.

Therefore, the interpretation of EB I copper axes in these terms, having metal weapons a special value in virtue of complex system of production and rarity of raw material, seems likely, considering, on one side, the close relation with double-apses building, ${ }^{147}$ and their noteworthy dimensions, and, on the other side, the association with a specific ceramic repertoire, placing itself in direct connection with previous Chalcolithic tradition. ${ }^{148}$

\section{REFERENCES}

BAR-ADON, P.

1980 The Cave of Treasure, the finds from the caves at Nahal Mishmar (Israel Exploration BRAUN, E.

1979 'En Shadud: Israel Exploration Journal 29 (1979), pp. 234-235.

1981 Khirbet 'Avot: Israel Exploration Journal 31 (1981), pp. 107-108.

1985 'En Shadud. Salvage Excavations at a Farming Community in the Jezreel Valley, Israel (British Archaeological Reports. International Series 249), Oxford 1985.

1989a The Problem of the Apsidal House: New Aspects of Early Bronze I Domestic Architecture in Israel, Jordan, and Lebanon: Palestine Exploration Quarterly 121 (1989), pp. 1-43.

1989b The Transition from the Chalcolithic to the Early Bronze Age I in Northern Israel and Transjordan: Is There a Missing Link?: P. DE MiRoschedJI (ed.), L'Urbanisation de la Palestine à l'âge du Bronze ancien. Bilan et perspectives des recherches actuelles. Actes du Colloque d'Emmaüs (20-24 octobre 1986) (British Archaeological Reports. International Series 527), Oxford 1989, pp. 7-27.

1991 Palmahim, Quarry - 1989/1990: Exploration and Survey in Israel 10 (1991), pp. 21-23.

1997 Khirbet Khalalidya/Yiftah'el. Salvage and Rescue Excavations at a Prehistoric Village in Lower Galilee, Israel (Israel Antiquities Authority Reports 2), Jerusalem 1997.

2000 Area G at Afridar, Palmahim Quarry 3 and the Earliest Pottery of Early Bronze Age I: Part of the 'Missing Link': G. PHILIP - D. BAIRD (eds.), Ceramics and Change in the Early Bronze Age of the Southern Levant (Levantine Archaeology 2), Sheffield 2000, pp. 113128.

2004 Early Beth Shan (Strata XIX-XIII): G. M. FitzGerald's Deep cut on the Tell (University Museum Monograph 121), Philadelphia 2004.

DE CONTENSON, H.

1960 Three Soundings in the Jordan Valley: Annual of the Department of Antiquities of Jordan IV-V (1960), pp. 12-98.

146 Nigro 2005, 123; Nigro 2007, 18; Faust - Golani 2008, 228-229.

147 Common value of this kind of buildings is stressed otherwise, in sites where were not recovered metal weapons, like as at Tell Kabri, where a seal impression with a human figure raising its arms standing next to a building, like as at Tell Teo and Tell Kabri, where some infant burials were found beneath floors.

148 Braun 1989b, 20; Nigro 2003, 65. 
1961 Remarques sur le Chalcolithique Récent de Tell esh Shuna: Revue Biblique 68 (1961), pp. 546-556.

DAR, S.

1989-1990 Axes from the Early Bronze Age at a Site Near Nahal Alexander: Bulletin of the AngloIsrael Archaeological Society 9 (1989-1990), pp. 46-52.

DOTHAN, M.

1957 Excavations at Meșer, 1956. Preliminary Report on the First Season: Israel Exploration Journal 7 (1957), pp. 217-228.

1958 Azor: Israel Exploration Journal 8 (1958), pp. 272-274.

1959 Excavations at Meser, 1957: Israel Exploration Journal 9 (1959), pp. 13-29

1960 Azor: Revue Biblique 67 (1960), pp. 395-396.

DUNAND, M.

1950 Chronologie des plus anciennes installations de Byblos: Revue Biblique 57 (1950), pp. 583-603.

1973 Fouilles de Byblos. Tome V. L'architecture, les tombes, le matériel domestique, des origines néolithiques à l'avènement urbain, Paris 1973.

EISENBERG, E.

1993 A Settlement from the Beginning of the Early Bronze Age I at Moza: 'Atiqot 22 (1993), pp. 41-48.

EISENBERG, E. - GOPHER, A. - GREENBERG, R

2001 Tel Te'o. A Neolithic, Chalcolithic, and Early Bronze Age Site in the Hula Valley (Israel Antiquities Authority 13), Jerusalem 2001.

ENEA, A.

1996 Per una rilettura delle abitazioni palestinesi a pianta curvilinea del Bronzo Antico I: Vicino Oriente 10 (1996), pp. 85-103.

ENGBERG, R.M. - SHIPTON, G.M.

1934 Notes on the Chalcolithic and Early Bronze Age Pottery of Megiddo (Studies in the Ancient Oriental Civilization 10), Chicago 1934.

FANTALKIN, A

2000 A Salvage Excavation at an Early Bronze Age Settlement on Ha-Shophtim Street, Qiryat 'Ata: Tel Aviv 27 (2000), pp. 28-56.

FAUST, A. - GOLANI, A.

2008 A Community in Transition: The Early Bronze Age Site of Qiryat Ata as a Test Case: $T e l$ Aviv 35 (2008), pp. 215-243.

FISHER, P.M.

2008 Tell Abu al-Kharaz in the Jordan Valley. Volume I: The Early Bronze Age (Österreichische Akademie der Wissenschaften Denkschriften der Gesamtakademie 48), Wien 2008.

FitzGerald, G.M.

1934 Excavations at Beth Shan in 1933: Palestine Exploration Fund. Quarterly Statement 67 (1934), pp. 123-134.

1935 Beth Shan: Earliest Pottery: The Museum Journal 24 (1935), pp. 5-22.

FRANKEL, R. - KEMPINSKI, A.

1973 Bet Ha-'Emeq: Israel Exploration Journal 23 (1973), pp. 242-243.

GiBSON, S. - IBBS, B. - KLONER, A.

1991 The Safat Project of Landscape Archaeology in the Judean Hills: A Preliminary Report on Four Seasons of Survey and Excavation (1987-89): Levant 23 (1991), pp. 29-54. 
GLUECK, N.

$1951 \quad$ Explorations in Eastern Palestine, IV, Part I (Annual of the American Schools of Oriental GOLANI, A. Research 25-28), New Haven 1951.

1999 New Perspectives on Domestic Architecture and the Initial Stages of Urbanization in Canaan: Levant 31 (1999), pp. 123-133.

2003 Salvage Excavations at the Early Bronze Age Site of Qiryat Ata (Israel Antiquities Authority Reports 18), Jerusalem 2003.

2004 Salvage Excavations at the Early Bronze Age Site of Ashqelon, Afridar - Area E: 'Atiqot 45 (2004), pp. 9-62.

2008 The Early Bronze Age Site of Ashqelon, Afridar - Area M: 'Atiqot 60 (2008), pp. 18-51. GOREN, Y. - ZuCKERMAN, S.

2000 An Overview of the Typology, Provenance and Technology of the Early Bronze Age I 'Grey Burnished Ware': G. PHILIP - D. BAIRD (eds.), Ceramics and Change in the Early Bronze Age of the Southern Levant (Levantine Archaeology 2), Sheffield 2000, pp. 165182.

Gustavson-Gaube, C.

1985 Tell esh-Shuna North 1984: A Preliminary Report: Annual of the Department of Antiquities of Jordan XXIX (1985), pp. 43-88.

HELMS, S.W.

1984 Excavations at Tell Umm Hammad esh-Sharqiya in the Jordan Valley, 1982: Levant 16 (1984), pp. 35-54.

1986 Excavations at Tell Um Hammad, 1984: Levant 18 (1986), pp. 25-50.

HESTRIN, R. - TADMOR, M.

1963 A Hoard of Tools and Weapons from Kfar Monash: Israel Exploration Journal 13 (1963), pp. $265-288$.

KEMPINSKI, A.

1978 The Rise of an Urban Culture: the Urbanization of Palestine in the Early Bronze Age, 3000-2150 B.C. (Israel Ethnographic Society 4), Jerusalem 1978.

2002 Miscellaneous Seals and Seal Impressions: N. SCHEFTELOWITZ - R. OREN (eds.), Tel Kabri: The 1986-1993 Excavations (The Emery and Claire Yass Publications in Archaeology. Monograph Series of the Institute of Archaeology of Tel Aviv University 20), Tel Aviv 2002, pp. 339-340.

KEMPINSKI, A. - NIEMEIER, W.D.

1991 Tel Kabri, 1989-1990: Israel Exploration Journal 41 (1991), pp. 188-194.

LANKESTER HARDING, G.

$1954 \quad$ Vallée du Jordain: Revue Biblique 61 (1954), pp. 560-561.

LEONARD, A.JR.

1992 The Jordan Valley Survey, 1953: Some Unpublished Soundings Conducted by James Mellaart (Annual of American Schools of Oriental Research 50), Winona Lake 1992.

MARQueT-Krause, J.

1949 Les Fouilles de 'Ay (Et-Tell) 1933-1935 (Institut Français d'Archéologie de Beyrouth. Bibliothèque Archéologique et Historique XLV), Paris 1949.

MAZAR, A. - ROTEM, Y.

2009 Tel Beth Shan During the EB IB Period: Evidence for Social Complexity in the Late 4th Millennium BC: Levant 41 (2009), pp. 131-153.

Miron, E.

1992 Axes and Adzes from Canaan (Prähistorische Bronzefunde 9), Stuttgart 1992. 
Nicolle, C. - BRAEMER, F.

2012 Settlement Networks in the Southern Levant in the Mid $4^{\text {th }}$ Millennium BC: Sites with Double-Apses Houses in the Leja Area of the Southern Syria During the EBA IA: Levant 44 (2012), pp. 1-16.

NigRO, L.

2003 Dal rame al bronzo (senza trascurare l'oro e l'argento). La metallurgia e la nascita delle città-stato in Siria e Palestina nel III millennio a.C.: G. CAPRIOTTI VitozZI (ed.), L'uomo, la pietra, i metalli. Tesori della terra dal Piceno al Mediterraneo, San Benedetto del Tronto 2003, pp. 62-69.

2005 Tell es-Sultan/Gerico. Alle soglie della prima urbanizzazione: il villaggio e la necropoli del Bronzo Antico I (3300 - 300 a.C.) (Rome «La Sapienza» Expedition to Palestine and Jordan 1), Roma 2005.

2006 Alcuni vasi del Bronzo Antico I (3300-3000 a.C.) in Ceramica grigia lustrata dalla necropoli di Gerico nei Musei Vaticani: Bollettino dei Monumenti, Musei e Gallerie Pontificie XXV (2006), pp. 7-32.

2007 Aside the Spring: Byblos and Jericho from Village to Town in the Second Half of $4^{\text {th }}$ Millennium BC: L. Nigro (ed.), Byblos and Jericho in the Early Bronze Age I. Social Dynamics and Cultural Interactions (Rome «La Sapienza» Expedition to Palestine and Jordan 4), Roma 2007, pp. 1-45.

PERROT, J.

1963 Munhata: Revue Biblique 70 (1963), pp. 560-563.

PHILIP, G.

1988 Hoards of the Early and Middle Bronze Ages in Levant: World Archaeology 20 (1988), pp. 190-208.

REICH, R.

1988-1989 Palmahim: Exploration and Survey in Israel 7-8 (1988-1989), p. 144.

ROWAN, Y.M.

2003 The Groundstone Assemblage: A. Golani, Salvage Excavations at the Early Bronze Age Site of Qiryat Ata (Israel Antiquities Authority Reports 18), Jerusalem 2003, pp. 183-202.

SAIDAH, R.

1979 Fouilles de Sidon - Dakerman: L'agglomération chalcolithique: Berytus 27 (1979), pp. 29-55.

SALA, M

2005 Le produzioni ceramiche gerichiote del Bronzo Antico I: materiali stratificati provenienti dal tell: L. Nigro, Tell es-Sultan/Gerico. Alle soglie della prima urbanizzazione: il villaggio e la necropoli del Bronzo Antico I (3300 - 300 a.C.) (Rome «La Sapienza» Expedition to Palestine and Jordan 1), Roma 2005, pp. 167-178.

SALEM, H.J.

2006 Early Bronze Age Settlement System and Village Life in the Jenin Region/Palestine. A Study of Tell Jenin Stratigraphy and Pottery Traditions (https://openaccess.leidenuniv.nl/handle/1887/4360).

SCHEFTELOWITZ, N.

2002a Stratigraphy, Architecture and Tombs. Area B: N. ScheftelowiTZ - R. OREN (eds.), Tel Kabri: The 1986-1993 Excavations (The Emery and Claire Yass Publications in Archaeology. Monograph Series of the Institute of Archaeology of Tel Aviv University 20), Tel Aviv 2002, pp. 19-29.

2002b Pottery. Early Bronze Age: N. Scheftelowitz - R. Oren (eds.), Tel Kabri: The 19861993 Excavations (The Emery and Claire Yass Publications in Archaeology. Monograph 
Series of the Institute of Archaeology of Tel Aviv University 20), Tel Aviv 2002, pp. 96108

SHALEV, S.L. - BRAUn, E.

1997 The Metal Objects from Yiftah'el II: E. Braun (ed.), Yiftah'el. Salvage and Rescue Excavations at Prehistoric Village in Lower Galilee, Israel (Israel Antiquities Authority 2), Jerusalem 1997, pp. 92-96.

TADMOR, M. - PRAUSNITZ, M.

1959 Excavations at Rosh Hanniqra: 'Atiqot 2 (1959), pp. 72-88.

THOMPSON, H.O.

1969 Apsidal Construction in the Ancient Near East: Palestine Exploration Quarterly 101 (1969), pp. 69-86.

WRIGHT, G.E.

1937 The Pottery of Palestine from the Earliest Times to the End of the Early Bronze Age (American Schools of Oriental Research Publications of the Jerusalem School. Archaeology 1), New Haven 1937.

1958 The Problem of Transition Between the Chalcolithic and Bronze Ages: Eretz Israel 5 (1958), pp. 37-45.

YANNAI, E.

1999 New Typological and Technological Aspects of Grey Burnished Bowls in Light of the Excavation at 'Ain Assawir: Tel Aviv 26 (1999), pp. 208-224.

2006 'En Esur ('Ein Asawir) I. Excavations at a Protohistoric Site in the Coastal Plain of Israel (Israel Antiquities Authority Reports 31), Jerusalem 2006.

YANNAI, E. - LAZAR-SHORER, D. - GROSINGER, Z.

2006 The Pottery Assemblage: 'En Esur ('Ein Asawir) I. Excavations at a Protohistoric Site in the Coastal Plain of Israel (Israel Antiquities Authority Reports 31), Jerusalem 2006, pp. 63-178. 


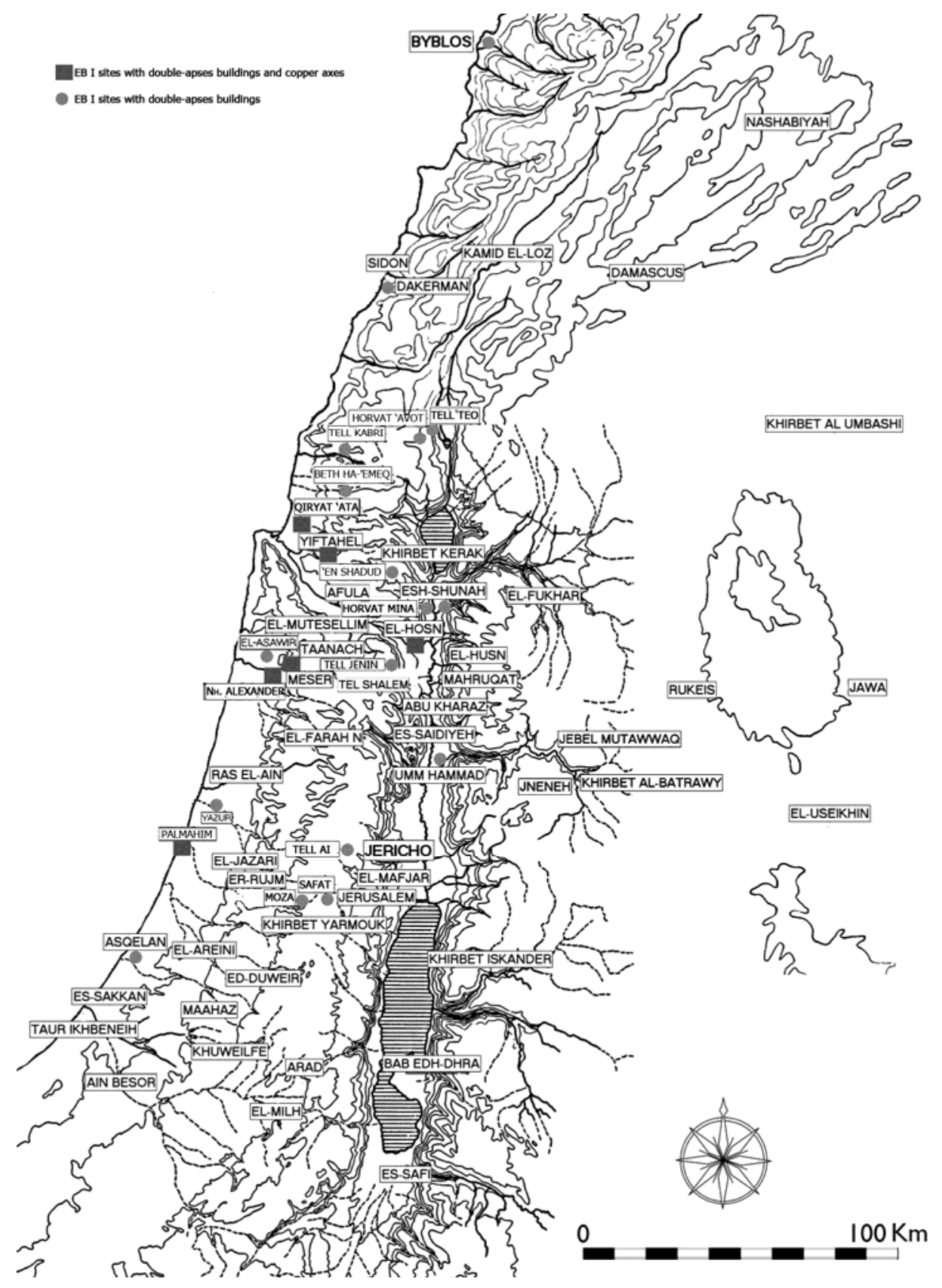

Fig. 1: EB I major sites in Southern Levant; dots indicate sites with double-apses buildings, squares indicate sites with double apses-buildings and copper axes. 

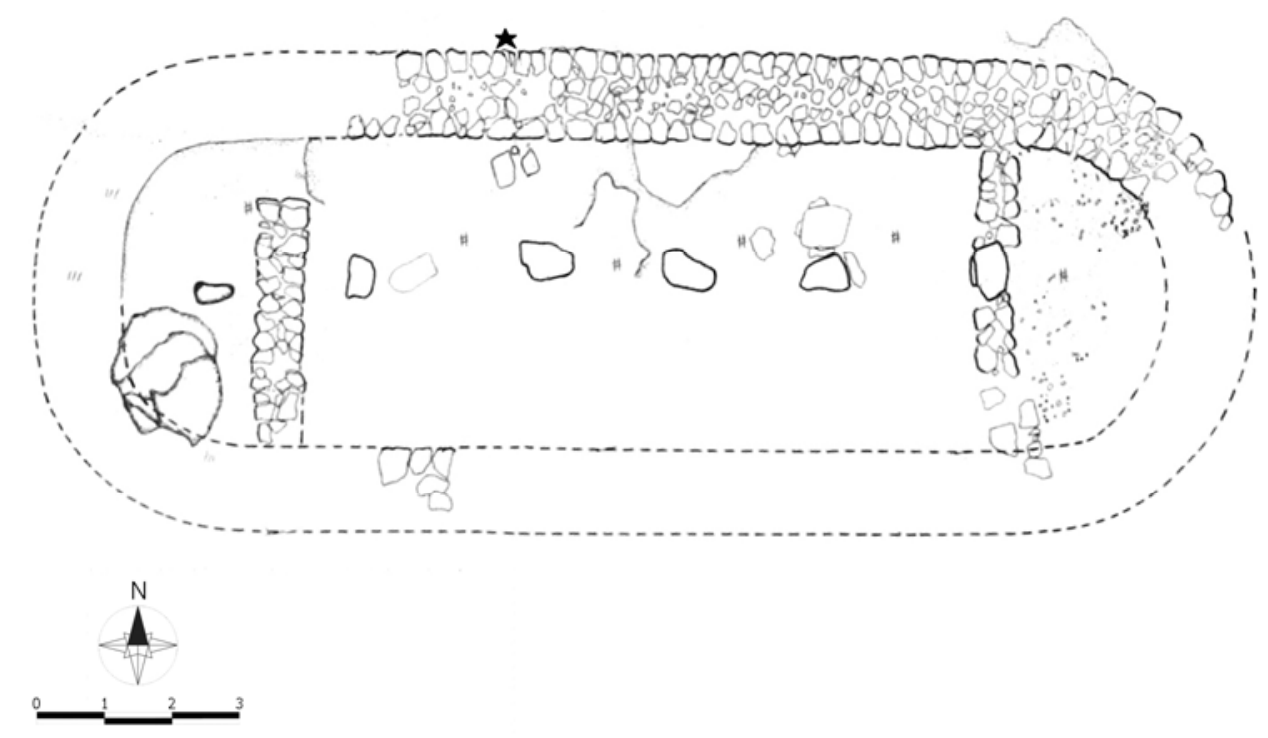

Fig. 2: Plan of Building 2 of Qiryat 'Ata (after Golani 2003, plan 2:3), EB IB; the star indicates the finding place of the cache of copper tools.

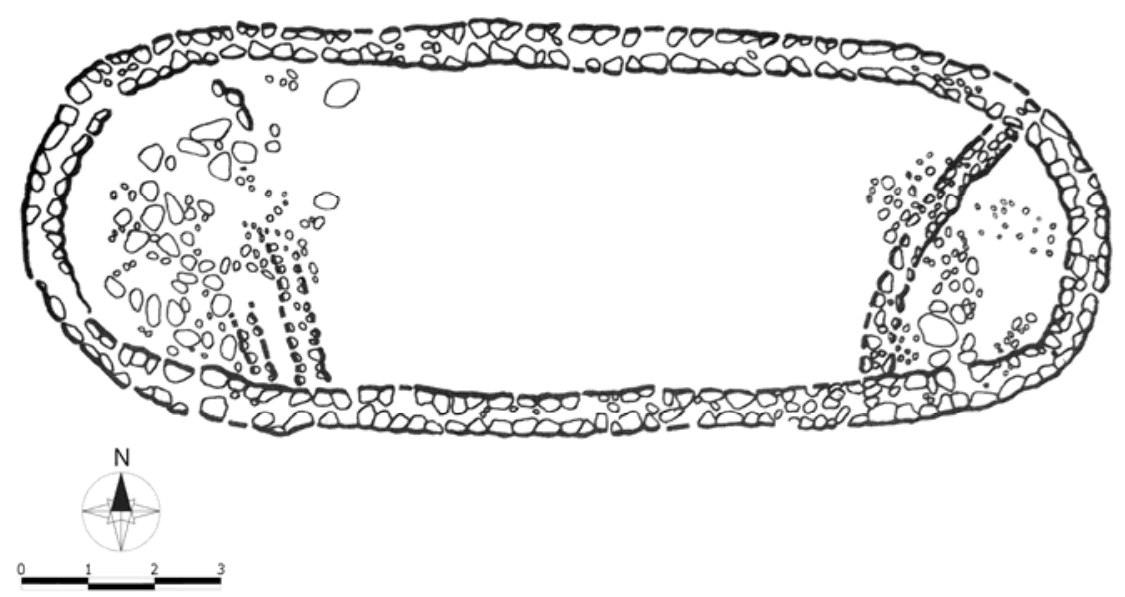

Fig. 3: Plan of Building IIA/1 of Khirbet Khalalidya/Yiftah'el (after Braun 1997, plan 3), EB IA. 


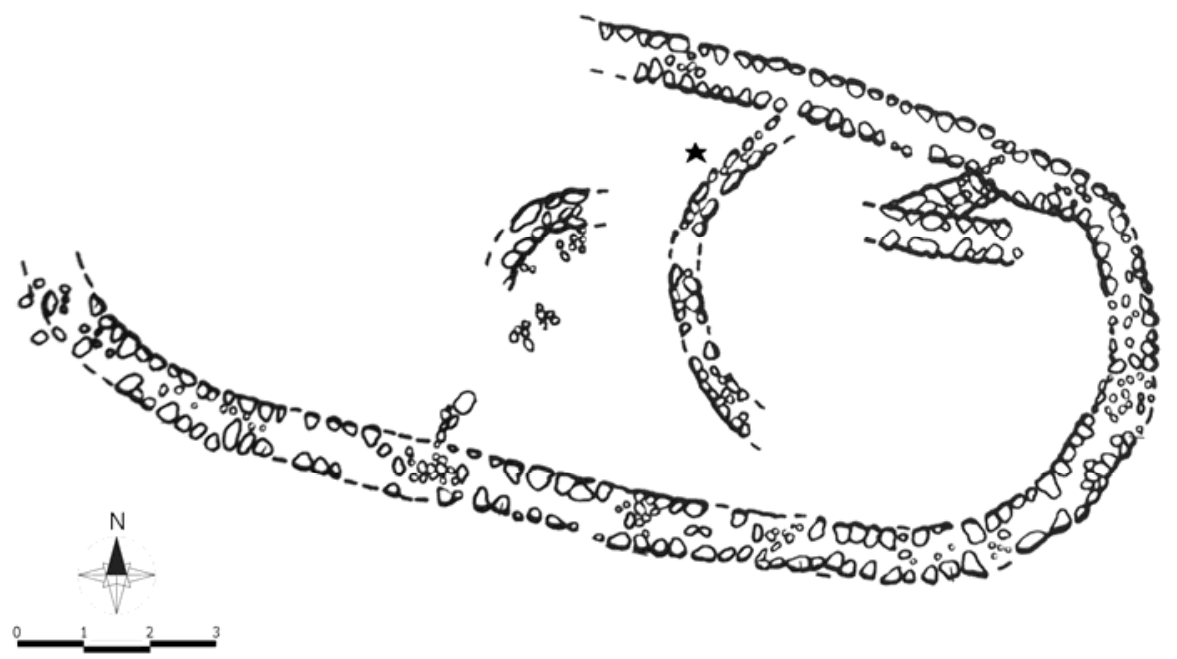

Fig. 4: Plan of Building IIB/1 of Khirbet Khalalidya/Yiftah'el (after Braun 1997, plan 4), EB IA; the star indicates the finding place of the copper axe.

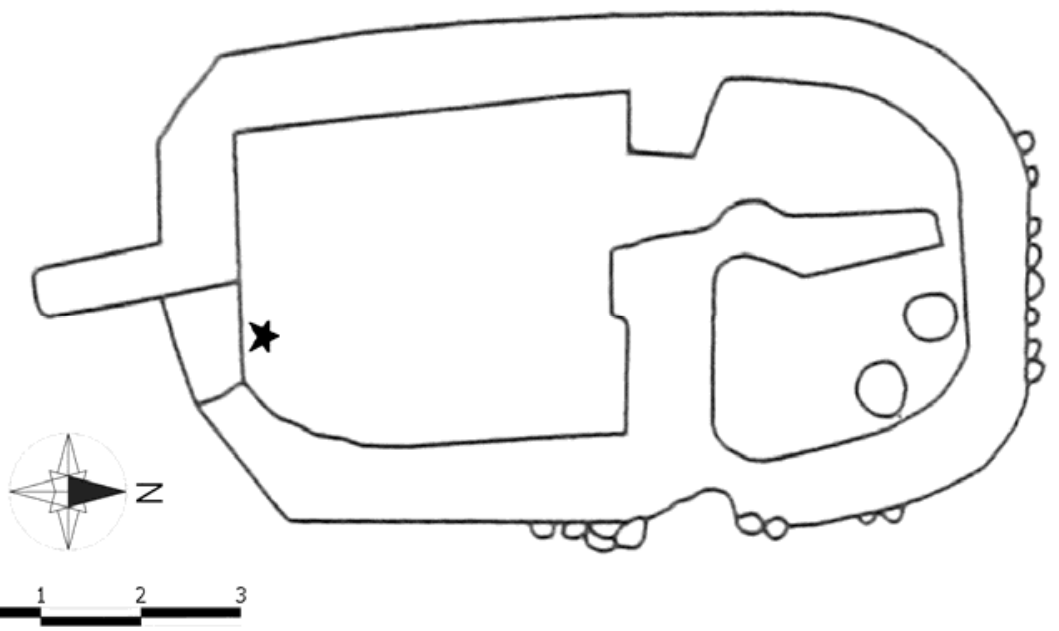

Fig. 5: Plan of the double-apses building of Level XVI of Tell el-Hosn/Beth Shan (after Braun 2004, fig. 2:15), EB IA; the star indicates the finding place of the copper axe and adze. 


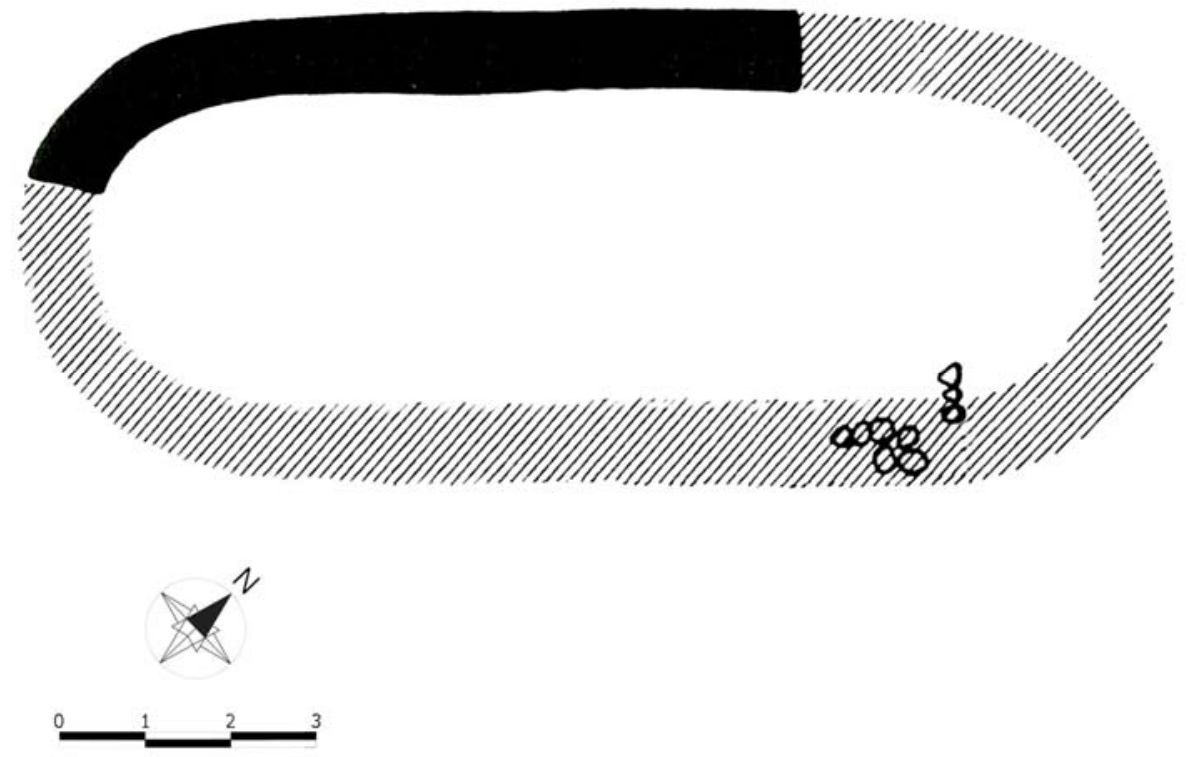

Fig. 6: Plan of suggested reconstruction of the curvilinear wall of Stratum II of Khirbet Sheikh Meser/Meser (after Braun 1989a, fig. 6), EB IA. 


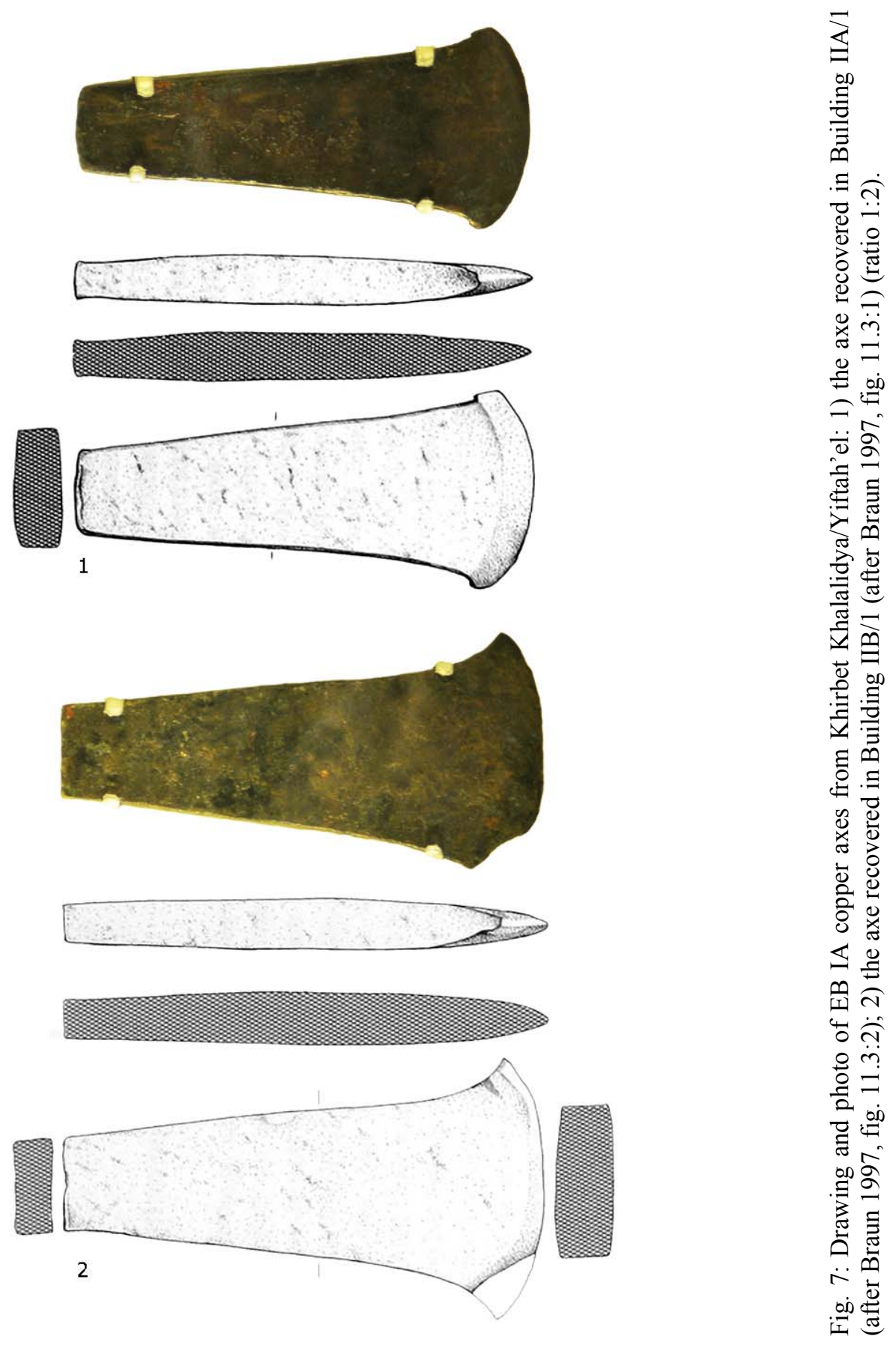



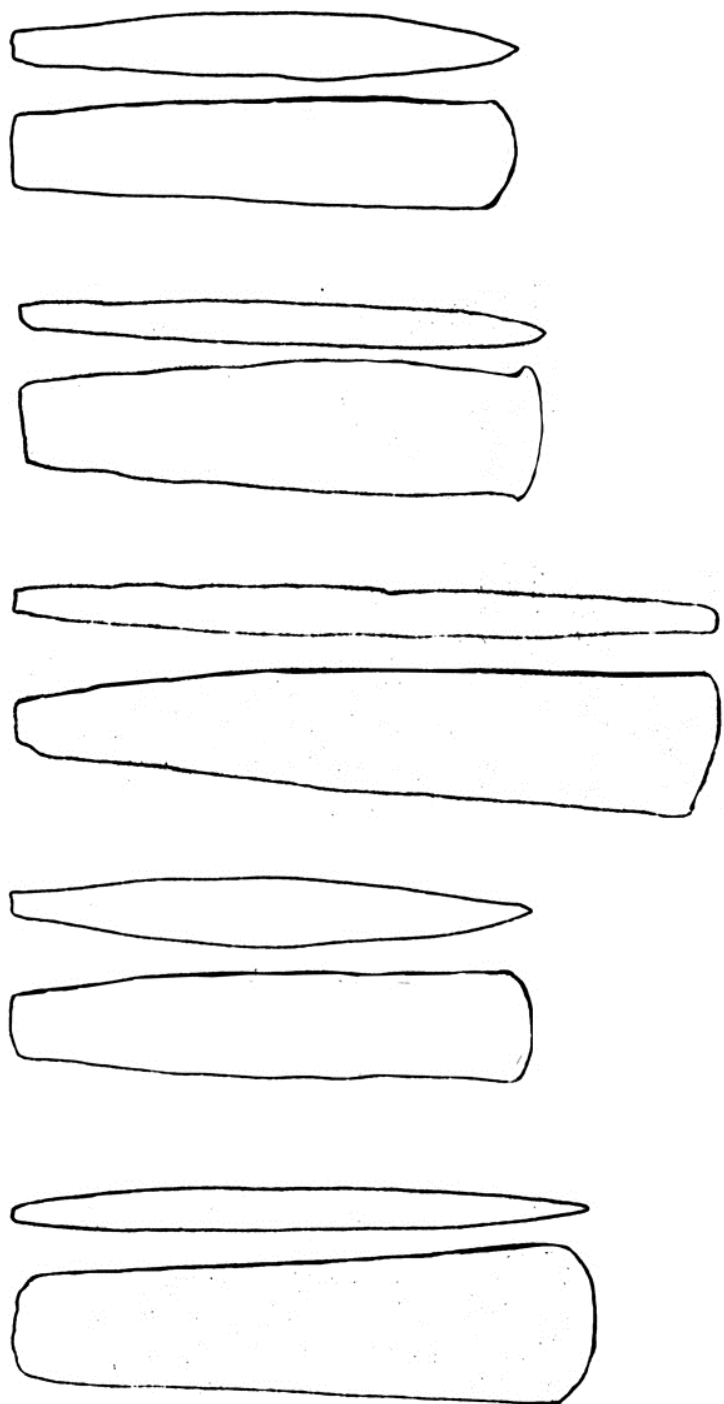

Fig. 8: Drawing of five copper axes recovered at Khirbet Sheikh Meser/Meser, EB IA (after Miron 1992, pls. 2:29-30, 3:31-33) (ratio 1:4). 


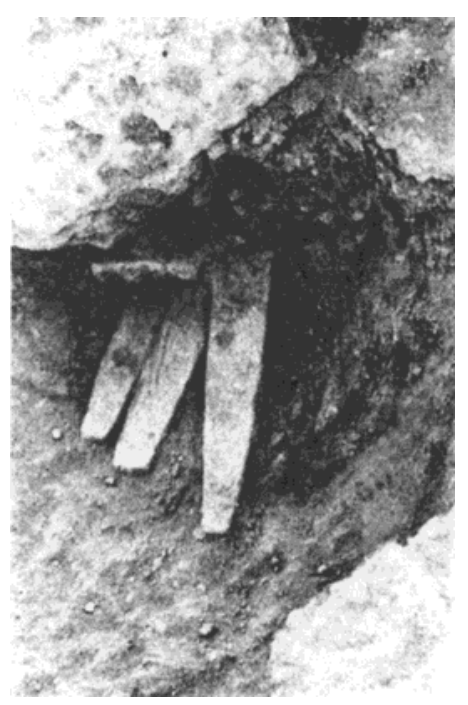

Fig. 9: Photo of copper axes hoard recovered in the site of Khirbet Sheikh Meser/Meser under the curvilinear wall, EB IA (after Dothan 1957, pl. 37:C).
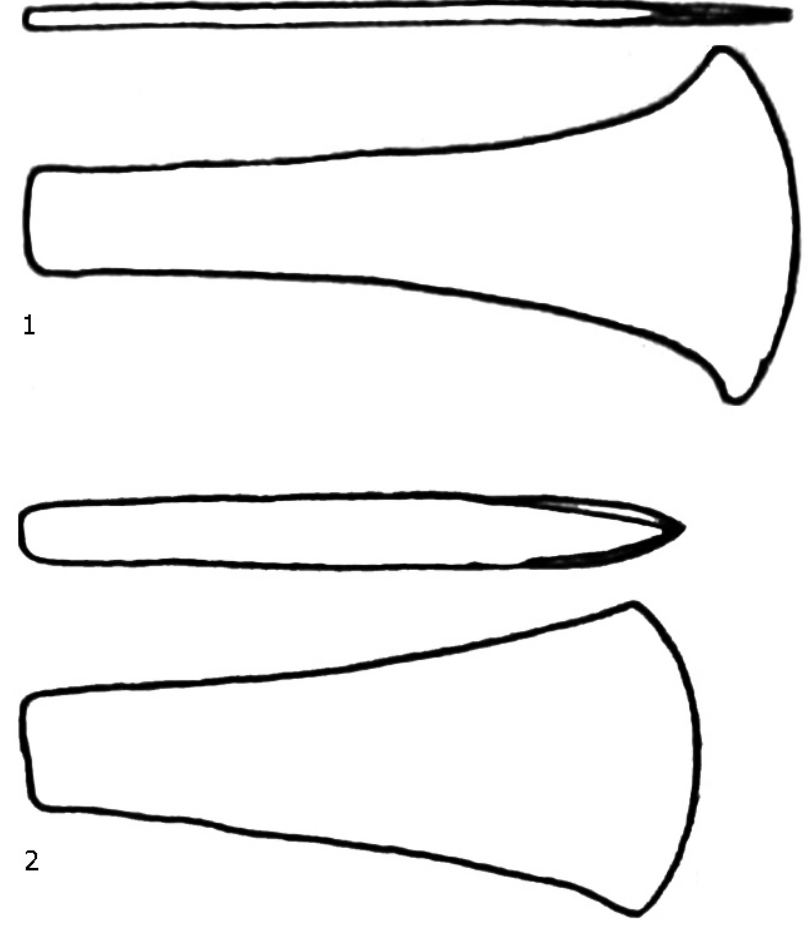

Fig. 10: Drawing of copper axe (1) and adze (2) recovered in the double-apses building of Tell el-Hosn/Beth Shan, EB IA (after FitzGerald 1935, pl. III:21, 23, respectively) (ratio $1: 2)$. 


\section{\%}
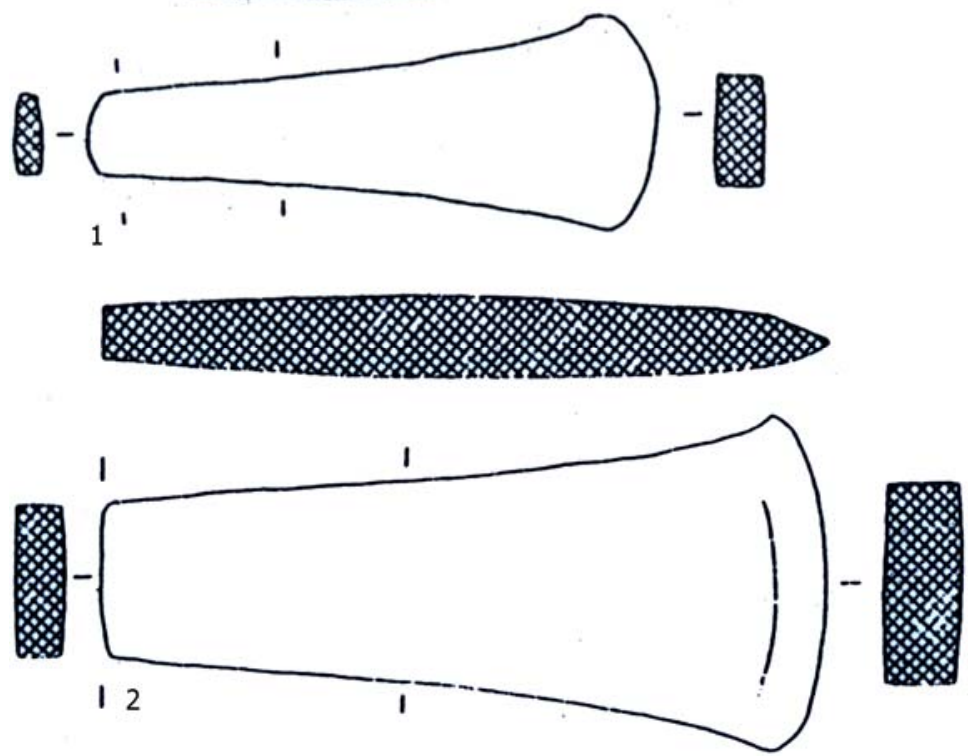

Fig. 11: Drawing of copper axes recovered at Palmahim Quarry, EB IA (after Reich 1988-1989, 144) (ratio 1:2).

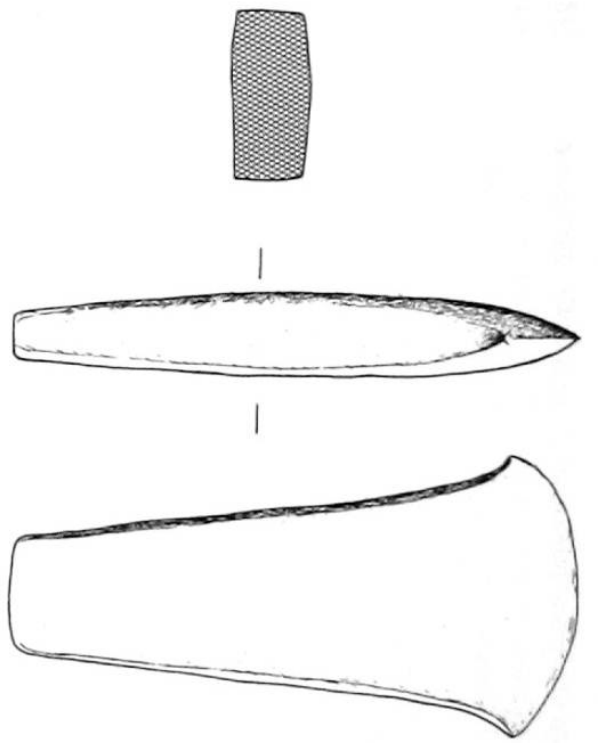

Fig. 12: Drawing of the copper axe found in the Building 2 of Qiryat 'Ata, EB IB (after Golani 2003, fig.7:6:1) (ratio 1:2). 

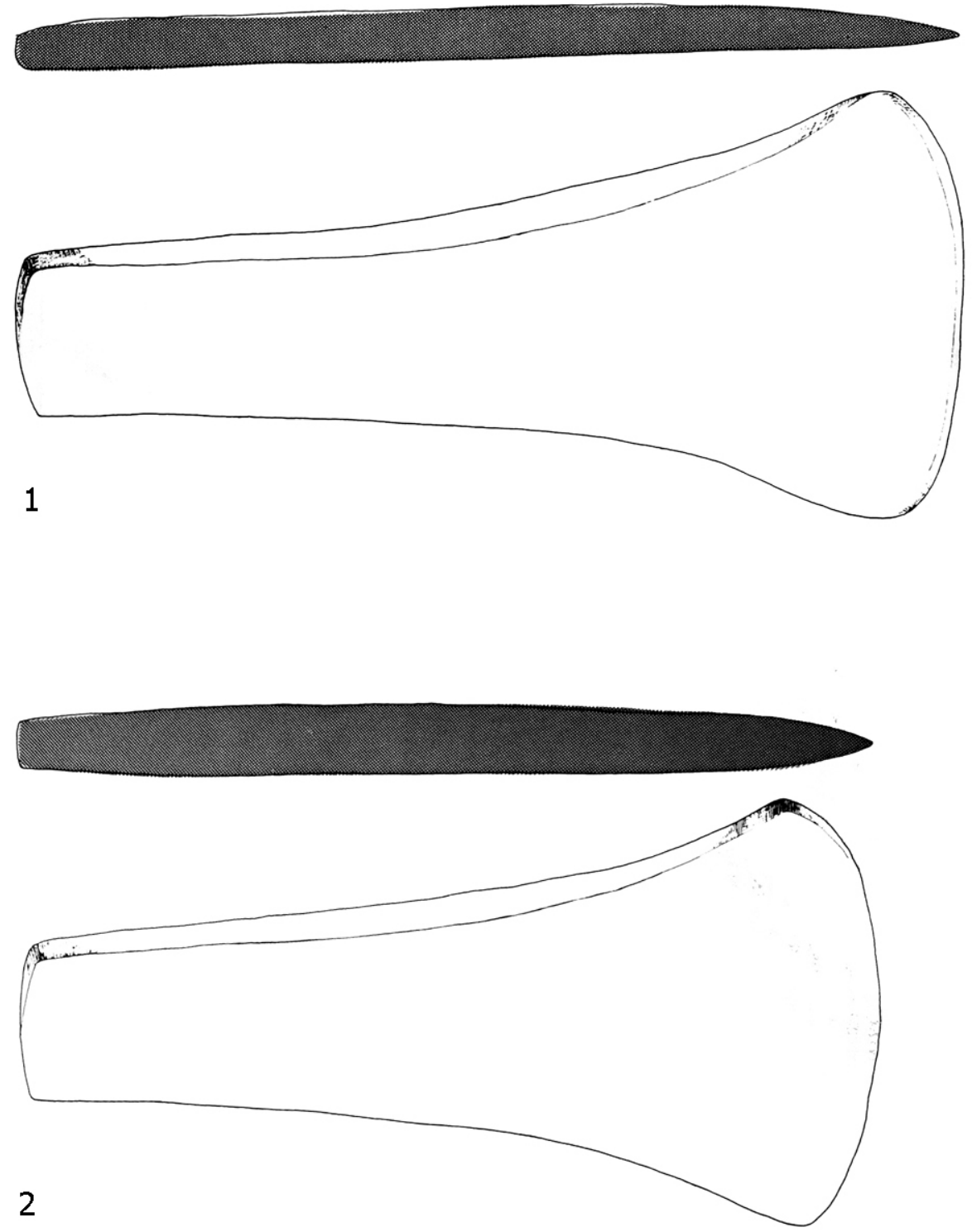

Fig. 13: Drawing of two among five copper axes recovered in Nahal Alexander, EB I (after Dar 1989-1990, figs. 2-3) (ratio 1:2). 


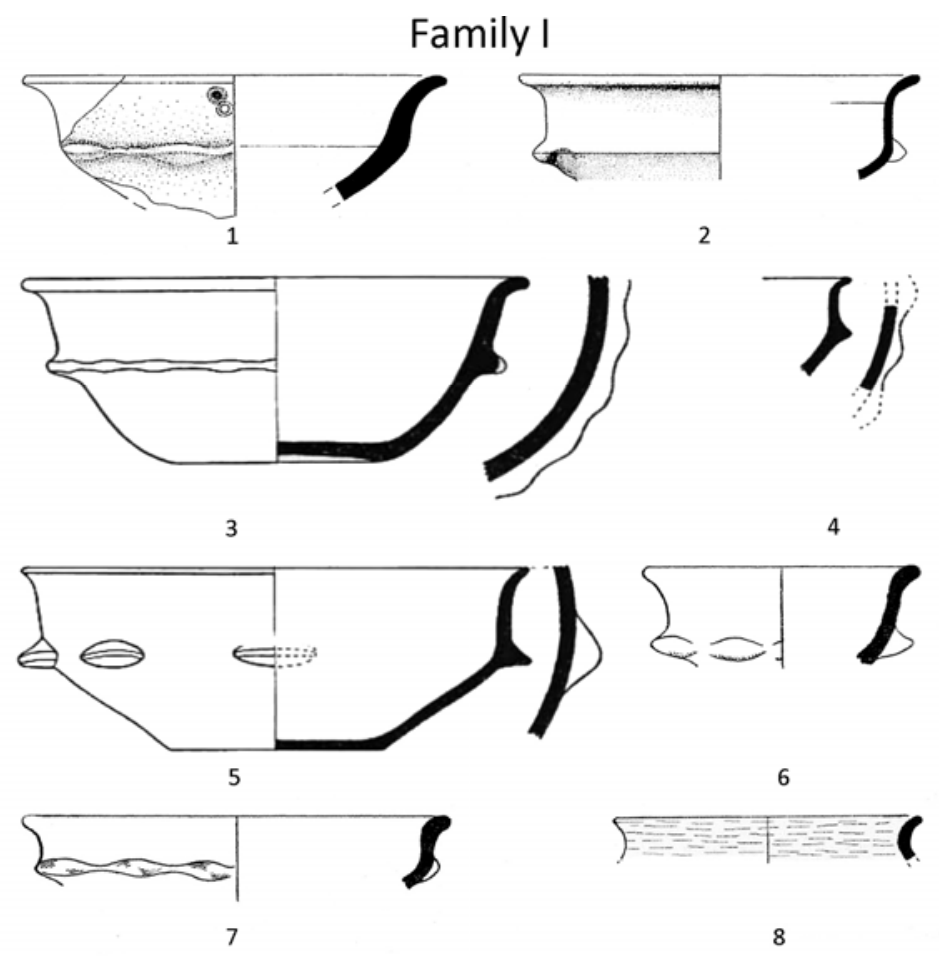

Family III

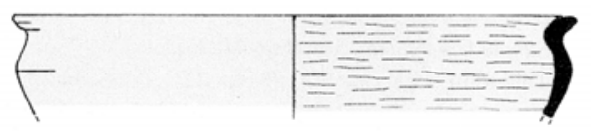

9

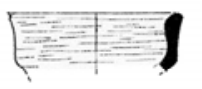

10
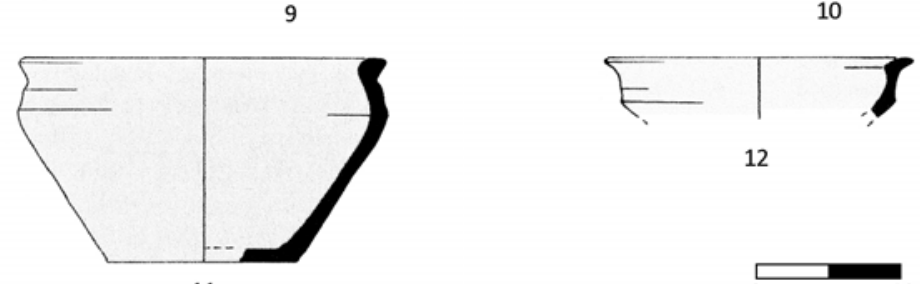

12

1

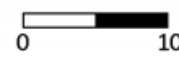

Fig. 14: GBW bowls recovered in connection with double-apses buildings. Family I: 1, Building IIB/1 at Khirbet Khalalidya/Yiftah'el, EB IA (after Braun 1997, fig. 9:2:7); 2, Building IIA/1 at Khirbet Khalalidya/Yiftah'el, EB IA (after Braun 1997, fig. 9:2:8); 3-5, Tell el-Hosn/Beth Shan Level XVI, EB IA (after FitzGerald 1935, pl. III:1-2, 4); 6-7, Khirbet Sheikh Meser/Meser Stratum II, EB IA (after Dothan 1957, fig. 2:2-3); 8, Building II of Qiryat 'Ata, EB IB (after Golani 2003, fig. 4.2:17); Family III: 9-12, Building II of Qiryat 'Ata, EB IB (after Golani 2003, pl. 4:2:17, 10, 1, 9, 6). 